\title{
Unique invariant $\mathrm{CD}^{+} \mathrm{T}$ cell population persists in MS
}

\section{OPEN}

Joseph J. Sabatino, Jr, $\mathrm{MD}, \mathrm{PhD}$

Scott S. Zamvil, MD, $\mathrm{PhD}$

Correspondence to

Dr. Zamvil:

zamvil@ucsf.neuroimmunol.org

Neurol Neuroimmunol Neuroinflamm

2015;2:e140; doi: 10.1212/ NXI.0000000000000140
Although historically overshadowed by $\mathrm{CD}^{+} \mathrm{T}$ cells, and more recently by $\mathrm{B}$ cells, a number of lines of evidence point toward a potentially vital role of $\mathrm{CD}^{+} \mathrm{T}$ cells in multiple sclerosis (MS) pathogenesis. $\mathrm{CD}^{+}{ }^{+} \mathrm{T}$ cells outnumber $\mathrm{CD}^{+}{ }^{+}$in the parenchyma of MS lesions ${ }^{1}$ and are abundant at the leading edge in chronic active lesions. ${ }^{2}$ Some studies have detected increased frequencies of myelin-specific $\mathrm{CD} 8^{+} \mathrm{T}$ cells in patients with MS. ${ }^{3,4}$ Human leukocyte antigen (HLA)-A3 ( $\left.{ }^{*} 0301\right)$, which encodes one of the major histocompatibility complex (MHC) class I proteins used for antigen recognition by $\mathrm{CD} 8^{+} \mathrm{T}$ cells, doubles the risk of MS even in the absence of HLA-DR2 (DRB*1501, DQB*0602) genes that encode MHC II proteins used for antigen presentation to $\mathrm{CD}^{+} \mathrm{T}$ cells. ${ }^{5}$ Furthermore, it has been demonstrated that myelin-specific $\mathrm{CD}^{+}{ }^{+} \mathrm{T}$ cells can induce an MS-like disease in HLA-A3 transgenic ${ }^{6}$ and wild-type mice. ${ }^{7}$ If antigen-specific $\mathrm{CD}^{+} \mathrm{T}$ cells participate in MS pathogenesis, one might ask whether certain ones expand selectively and whether they persist.

In this issue of Neurology ${ }^{\circledR}$ Neuroimmunology \& Neuroinflammation, Held et al. examined $\mathrm{CD}^{+} \mathrm{T}$ cells in 1 patient with MS over 18 years. ${ }^{8}$ A brain biopsy shortly after presentation demonstrated inflammatory demyelination. Using high-throughput Next Generation Sequencing, these investigators examined the $\mathrm{CD}^{+} \mathrm{T}$ cell repertoire in this $\mathrm{MS}$ lesion and compared it to that found in the peripheral blood at subsequent time points. Each T cell recognizes a unique antigen and its specificity is primarily shaped by the combination of T cell receptor (TCR) $\alpha$ and $\beta$ chain complementarity determining region (CDR) 3 regions, which are each formed by genetic recombination that links individual $V \alpha-J \alpha$ segments and separately connects $\mathrm{V} \beta-\mathrm{D} \beta-\mathrm{J} \beta$ sequences. Because the naive $\mathrm{T}$ cell repertoire is highly diverse, identification of a narrow array of $\mathrm{T}$ cell receptors in a particular location suggests clonal expansion of a small subset of antigen-specific $\mathrm{T}$ cells. Oligoclonal
$\mathrm{CD}^{+} \mathrm{T}$ cell populations in the blood, CSF, and brain of patients with MS were previously observed by TCR V $\beta$ sequencing. ${ }^{1,9}$ Held et al. took their clonal analysis a step further by combining the use of laser microdissection and single-cell PCR sequencing to analyze both the TCR $\alpha$ and $\beta$ chains within individual $\mathrm{CD} 8^{+} \mathrm{T}$ cells. They observed that a particular $\mathrm{CD}^{+} \mathrm{T}$ cell clonotype bearing the V $\beta 1-\mathrm{J} \beta 2.3$ TCR $\beta$ chain was expanded in active brain lesions and that this dominance persisted. Surprisingly, their analysis revealed that the subset of $\mathrm{CD} 8^{+} \mathrm{V} \beta 1^{+} \mathrm{T}$ cell clones contained $\alpha$ chains bearing the same $\mathrm{CDR} 3 \alpha$ sequence, $\mathrm{V} \alpha 7.2-\mathrm{J} \alpha 33$, that is unique to mucosal-associated invariant $\mathrm{T}$ (MAIT) cells, an innate-like $\mathrm{CD}^{+} \mathrm{T}$ cell subset that accounts for up to $4 \%$ of peripheral $\mathrm{T}$ cells in humans. ${ }^{10}$ MAIT cells are identified by coexpression of CD161, which has been associated with secretion of proinflammatory cytokines, including interleukin-17. They are restricted by a unique nonpolymorphic MHC I-like molecule, MR1. ${ }^{10}$ Unlike classic MHC I-restricted $\mathrm{CD} 8^{+} \mathrm{TCR} \alpha / \beta^{+} \mathrm{T}$ cells, which recognize peptide antigens, MAIT cells recognize bacterial-derived metabolites, in particular derivatives of riboflavin, and are dependent on gut microbiota for their development. Even though MAIT cells made up only $1 \%$ of all $\mathrm{CD}^{+} \mathrm{T}$ cells in MS brain lesions examined, persistent MAIT cell-related clonal populations were found in the blood 18 years after clinical onset. This is in contrast to other $\mathrm{CD}^{+} \mathrm{T}$ cells, which lost their preferential clonal expansion and became polyclonal, similar to $\mathrm{CD}^{+} \mathrm{T}$ cells. MAIT cells also exhibited a memory phenotype, indicating that they had been previously exposed to antigen. These results highlight the complexity of the $\mathrm{CD} 8^{+} \mathrm{T}$ cell repertoire in MS.

This report by Held et al. represents an important step forward in the analysis of the $\mathrm{T}$ cell repertoire found in MS. The degree of subclonal expansion of $\mathrm{V} \alpha 7.2^{+} / \mathrm{V} \beta 1^{+} \mathrm{CD} 8^{+} \mathrm{T}$ cells strongly suggests a local antigen-driven process, possibly within inflammatory

See article

\footnotetext{
From the Department of Neurology (J.J.S.), Johns Hopkins Hospital, Baltimore, MD; and Department of Neurology (S.S.Z.), University of California, San Francisco.

Funding information and disclosures are provided at the end of the article. Go to Neurology.org/nn for full disclosure forms. The Article Processing Charge for this editorial was waived at the discretion of the Editor.

This is an open access article distributed under the terms of the Creative Commons Attribution-NonCommercial-NoDerivatives License 4.0 (CC BY-NC-ND), which permits downloading and sharing the work provided it is properly cited. The work cannot be changed in any way or used commercially.
} 
MS lesions. A limitation of the analysis is that the antigen specificity of the clonally expanded $\mathrm{CD} 8^{+}$ $\mathrm{T}$ cells is not known. In the absence of CNS infection, bacterial products should not necessarily be present within the CNS. Although MAIT cells are known to recognize derivatives of vitamin $B_{2}$, it is currently unclear whether the nonpolymorphic MHC-like MR1 can present other antigens. Furthermore, because the studies were limited to a single patient, it is unclear whether similar clonal $\mathrm{CD}^{+} \mathrm{T}$ cell populations are found in other patients with MS. Most importantly, the clinical significance of invariant $\mathrm{CD}^{+} \mathrm{T}$ cells remains largely unknown. The presence of clonal $\mathrm{CD}^{+} \mathrm{T}$ cell populations in MS brain lesions shortly after clinical onset raises the possibility that these cells have an important pathogenic role in early MS. Therefore, it would be worthwhile to evaluate $\mathrm{CD}^{+} \mathrm{T}$ cell clonotypes during relapses and remissions in multiple patients with MS. The functions of invariant $\mathrm{CD} 8^{+} \mathrm{T}$ cells, such as cytokine secretion, cytolytic capabilities, and interactions with $\mathrm{CD}^{+} \mathrm{T}$ cells, have not been elucidated in MS. More detailed characterization of various $\mathrm{CD} 8^{+} \mathrm{T}$ cell populations is therefore needed in order to determine whether they participate in MS pathogenesis and, if so, whether they are proinflammatory or protective in MS. Natural killer (NK) T cells, another invariant $\mathrm{T}$ cell subset, recognize glycolipids, including myelin-derived sulfatide, via a nonpolymorphic MHC 1-like molecule, CD1d. Of interest, data suggest that NK T cells may have a protective role in MS. ${ }^{11}$ Currently, mice that selectively express MAIT cell-associated TCR $\alpha$ and $\beta$ chains exist. Thus, studying the role of $\mathrm{CD}^{+} \mathrm{T}$ cells and invariant $\mathrm{T}$ cell populations like MAIT cells in the gastrointestinal tract and the CNS in acute or spontaneous MS models may provide useful insight regarding their potential role in CNS autoimmunity. The work of Held et al. provides a foundation to further study invariant $\mathrm{CD}^{+} \mathrm{T}$ cells in MS.

\section{DISCLOSURE}

J.J. Sabatino reports no disclosures. S.S. Zamvil received honoraria for serving on data safety monitoring boards for MS trials conducted by BioMS, Teva Pharmaceuticals, Inc., and Eli Lilly and Co.; is a member of the clinical advisory board for the Myelin Repair Foundation; is deputy editor for Neurology: Neuroimmunology \& Neuroinflammation; holds a patent for aquaporin-4 peptides and methods for using same; received speaker honoraria from Biogen-Idec, Teva Neuroscience, and Genzyme; has consulted for Biogen-Idec, Teva Neuroscience, EMD-Serono, Genzyme, and Novartis; is on the speakers' bureau for Advanced Health Medica and Biogen-Idec; and received research support from NIH, NMSS, Guthy-Jackson Charitable Foundation, and June L. Maisin Foundation. Go to Neurology.org/nn for full disclosure forms.

\section{REFERENCES}

1. Skulina C, Schmidt S, Dornmair K, et al. Multiple sclerosis: brain-infiltrating $\mathrm{CD}^{+} \mathrm{T}$ cells persist as clonal expansions in the cerebrospinal fluid and blood. Proc Natl Acad Sci USA 2004;101:2428-2433.

2. Traugott U, Reinherz EL, Raine CS. Multiple sclerosis: distribution of $\mathrm{T}$ cell subsets within active chronic lesions. Science 2015;219:308-310.

3. Crawford MP, Yan SX, Ortega SB, et al. High prevalence of autoreactive, neuroantigen-specific $\mathrm{CD}^{+} \mathrm{T}$ cells in multiple sclerosis revealed by novel flow cytometric assay. Blood 2004;103:4222-4231.

4. Berthelot L, Laplaud DA, Pettré S, et al. Blood $\mathrm{CD}^{+} \mathrm{T}$ cell responses against myelin determinants in multiple sclerosis and healthy individuals. Eur J Immunol 2008;38: 1889-1899.

5. Fogdell-Hahn A, Ligers A, Grønning M, Hillert J, Olerup O. Multiple sclerosis: a modifying influence of HLA class I genes in an HLA class II associated autoimmune disease. Tissue Antigens 2000;55:140-148.

6. Friese MA, Jakobsen KB, Friis L, et al. Opposing effects of HLA class I molecules in tuning autoreactive $\mathrm{CD}^{+} \mathrm{T}$ cells in multiple sclerosis. Nat Med 2008;14:1227-1235.

7. Huseby ES, Liggitt D, Brabb T, et al. A pathogenic role for myelin-specific CD8(+) T cells in a model for multiple sclerosis. J Exp Med 2001;194:669-676.

8. Held K, Bhonsle-Deeng L, Siewert K, et al. $\alpha \beta$ T-cell receptors from multiple sclerosis brain lesions show MAIT cell-related features. Neurol Neuroimmunol Neuroinflamm 2015;2:e107; doi: 10.1212/NXI.0000000000000107.

9. Babbe H, Roers A, Waisman A, et al. Clonal expansions of CD8(+) $\mathrm{T}$ cells dominate the $\mathrm{T}$ cell infiltrate in active multiple sclerosis lesions as shown by micromanipulation and single cell polymerase chain reaction. J Exp Med 2000;192:393-404.

10. Ussher JE, Klenerman P, Willberg CB. Mucosal-associated invariant T-cells: new players in anti-bacterial immunity. Front Immunol 2014;5:1-9.

11. Jahng A, Maricic I, Aguilera C, et al. Prevention of autoimmunity by targeting a distinct, noninvariant CD1dreactive $\mathrm{T}$ cell population reactive to sulfatide. $\mathrm{J}$ Exp Med 2004;199:947-957. 


\title{
Neurology \\ Neuroimmunology \& Neuroinflammation
}

\author{
Unique invariant $\mathrm{CD8}^{+} \mathrm{T}$ cell population persists in MS \\ Joseph J. Sabatino, Jr and Scott S. Zamvil \\ Neurol Neuroimmunol Neuroinflamm 2015;2; \\ DOI 10.1212/NXI.0000000000000140
}

This information is current as of August 6, 2015

\section{Updated Information \& Services}

References

Subspecialty Collections

Permissions \& Licensing

Reprints including high resolution figures, can be found at:

http://nn.neurology.org/content/2/4/e140.full.html

This article cites 11 articles, 5 of which you can access for free at: http://nn.neurology.org/content/2/4/e140.full.html\#\#ref-list-1

This article, along with others on similar topics, appears in the following collection(s):

All Demyelinating disease (CNS)

http://nn.neurology.org//cgi/collection/all_demyelinating_disease_cns

All Immunology

http://nn.neurology.org//cgi/collection/all_immunology

Autoimmune diseases

http://nn.neurology.org//cgi/collection/autoimmune_diseases

Multiple sclerosis

http://nn.neurology.org//cgi/collection/multiple_sclerosis

Information about reproducing this article in parts (figures,tables) or in its entirety can be found online at:

http://nn.neurology.org/misc/about.xhtml\#permissions

Information about ordering reprints can be found online:

http://nn.neurology.org/misc/addir.xhtml\#reprintsus

Neurol Neuroimmunol Neuroinflamm is an official journal of the American Academy of Neurology.

Published since April 2014, it is an open-access, online-only, continuous publication journal. Copyright $\odot$ 2015 American Academy of Neurology. All rights reserved. Online ISSN: 2332-7812.

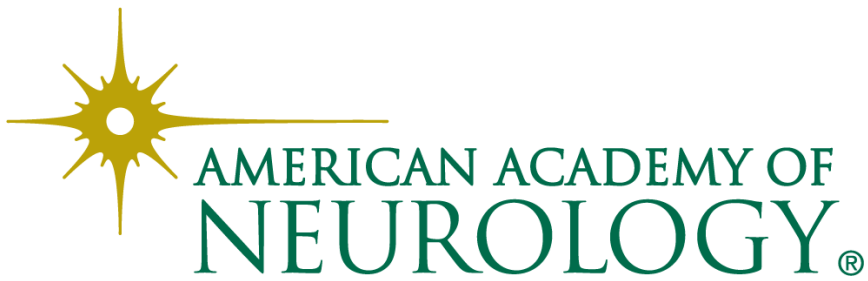

